\title{
The Psycho-Political Underpinnings of Presidential Speeches: President Buhari's Three Selected Speeches to Countrymen
}

\author{
Authors: Mike Omilusi \\ Submitted: $\quad$ 19. July 2019 \\ Published: $\quad$ 24. July 2019 \\ Volume: \\ Issue: \\ Affiliation: \\ Languages: \\ Keywords: \\ Categories: \\ DOI: \\ 6 \\ 7 \\ Department of Political Science. Ekiti State University, Nigeria. \\ English \\ Presidential Speeches, Psycho-Political, Historical Moments, \\ Persuasion \\ Humanities, Social Sciences and Law \\ 10.17160/josha.6.7.588
}

\section{Abstract:}

Given the fact that presidential persuasion is a central feature of presidential power and leadership, this essay explores the persuasive strategies employed by President Buhari in three selected speeches. Although much research has been done on the rhetoric of presidents at crucial moments in Nigeria, most of these studies focused on international affairs or linguistic appraisal rather than domestic socio-political situations. Interestingly, many of the essays on this subject matter are vagaries from columnists and journalists with seemingly partisan disposition. The thrust of this essay, therefore, is premised on the hypothesis that the three speeches were meant to strike the psychological and political minds of the citizenry during the period under review. Do the speeches reflect any ideological preference, espouse grounded policy framework or unravel novel ideas to knotty issues in the polity with a view to assuaging the tension-soaked polity? The methodology for conducting this analysis draws upon Thoemmes and Conwav's seminal work on intearative comnlexity It similarlv advances rhetorical nresidency as a

\section{JOSHA Jumana osaterea Humanities and Arts}




\title{
The Psycho-Political Underpinnings of Presidential Speeches: President Buhari's Three Selected Speeches to Countrymen
}

\author{
By Mike Omilusi
}

\begin{abstract}
Given the fact that presidential persuasion is a central feature of presidential power and leadership, this essay explores the persuasive strategies employed by President Buhari in three selected speeches. Although much research has been done on the rhetoric of presidents at crucial moments in Nigeria, most of these studies focused on international affairs or linguistic appraisal rather than domestic socio-political situations. Interestingly, many of the essays on this subject matter are vagaries from columnists and journalists with seemingly partisan disposition. The thrust of this essay therefore, is premised on the hypothesis that the three speeches were meant to strike the psychological and political minds of the citizenry during the period under review. Do the speeches reflect any ideological preference, espouse grounded policy framework or unravel novel ideas to knotty issues in the polity with a view to assuaging the tension-soaked polity? The methodology for conducting this analysis draws upon Thoemmes and Conway's seminal work on integrative complexity. It similarly advances rhetorical presidency as a theoretical instrument; focusing on a singular regime-presidency in Nigeria as against the usual practice of comparative analysis spanning different regimes.
\end{abstract}

Key Words: Presidential Speeches, Psycho-Political, Historical Moments, Persuasion 


\section{Introduction}

Presidents are often looked to for leadership and they have the advantage of making the news through their speeches and policy pronouncements. In fact, no other political leader is believed to have the ability to focus attention as clearly, or change the motivation of other actors in the political system than the president (Edwards and Wood, 1999). Political speeches are motivated by the desire to persuade and convince the nation or society and familiarize the audience with their socio-economic policies, plans and actions (Denton and Hahn, 1986; Teittinen, 2000)

According to Kamalu and Agangan (2011) political discourses like Independence speech, declaration of candidacy for political office, political campaigns, presentation of party manifestoes and other forms of political fall within the purview of deliberative rhetoric. They are aimed at marketing the ideology of the candidate or parties represented. Thus, studying national addresses can provide an account of presidential priorities during their presidency (Hughes, 2009). These studies are important because, by examining presidential rhetoric, researchers can use the data to determine if the president's issue agenda has an influence on legislation, the public or the media. Such findings could be beneficial to future agenda-setting researchers studying presidential influence (Hughes, 2009).

Politicians usually employ persuasive language to make the audience accept their ideology. As a matter of fact, they often employ emotional arguments and language to arouse the interest of the audience. Chilton (2004:3) defines politics as "a struggle for power, between those who seek to assert and maintain their power and those who seek to resist it". In other words, politicians usually use language and power to persuade the public either to take political actions or make political decisions. De Wet (2010:104) observes that -the language of political persuasion is geared to guiding recipients' attitudes and orientation/or behaviour, that is, to forming, sustaining or changing their attitudes on a political issue or impelling them to act. Although not always influential, speeches are a primary tool available to modern presidents to alter their current political situation and help them to govern (Eshbaugh-Soha, 2010:3).

Previous studies have focused on campaign speeches in Nigeria and tended to be a description and analysis of style, innovative and persuasive strategies of politicians, and manipulation of linguistic structures to champion individual interest in presidential election campaign speeches. The current study focuses on presidential messages not made during electioneering, but the content of presidential communication to countrymen at seeming annual ritual speeches or critical political moments as one case exemplifies among the case studies.

Also, the study analyses these speeches in order to understand the principles held by the president and the historical context in which the speeches were made. In particular, it examines the psycho-political relevance/influence of the speeches; their intended goals and whether the goals were actually achieved. Given the fact that presidential persuasion is a central feature of presidential power and leadership, this 
study explores the persuasive strategies- in terms of psychological and political underpinnings- used by President Buhari in three selected speeches.

Studying the effects of presidential speeches on public opinion at different historical moments in the polity is important in a number of ways. Presidential speeches play an important role in a political polity where the president, not only welds enormous power, but functions as a father-figure and role model. Although much research has been done on the rhetoric of presidents in times of crises, most of this research, as carried out in Nigeria for instance, focused on international affairs or linguistic appraisal rather than domestic socio-political situations. Interestingly, many of the write-ups on this area are vagaries from columnists and journalists with seemingly biased disposition as observable in the country.

\section{Conceptual Exploration of Presidential Speeches}

Political speech was considered by Thomas Jefferson and the other founders of the American Republic to be the heart of democracy. The speeches are usually held by leading politicians, who speak either to the nation as a whole or to a specific political group. The politicians who give the speeches usually do it as representatives of political groups such as political parties, governments or nations, rather than as individuals. What they are allowed to say and how is often very limited, because one of the main goals of giving a political speech is to enhance the credibility of the politician in question (Irimiea 2010:4). Political speeches are supposed to increase the population's political participation, help them to understand important issues and how a problem is best solved as well as a way for the politicians to persuade others to have the same opinions as them (Irimiea 2010:3).

Presidential speeches constitute one of the genres of political discourse which has received attention over the years. This has resulted in the various delineations and classifications of political speeches such as inaugural address, address to party congress, campaign speech and acceptance speech. Because public speeches and major addresses serve as the primary mode of communication between the President and the citizens of the country, the content of the President's speeches matters. These speeches are typically disseminated through a variety of media outlets including television, radio, magazines, and newspapers. As note by Eshbaugh-Soha (2010:1), speeches are vital to modern presidential governance. We know that speeches inform others of presidents' policy preferences and allow them to meet public expectations; yet we do not know precisely what influences presidents' tendencies to deliver them. Indeed, the existing literature is deficient in several ways. Along with providing mixed and inconsistent results, it does not unify around a cohesive theory to explain speechmaking (Eshbaugh-Soha, 2010:2). 
In contemporary pluralistic societies such as Germany, Great Britain, and the United States-where political voices have access to multiple forms of communication, including television, radio, newspapers, scholarly journals, and Internet driven social media - it is expected that any national level political event will be commented upon and analysed by both adherents and opponents. Never is this more true than when the leader of a nation, or a candidate to become that leader, speaks in any public forum (Williams et al, 2012:1744). The struggle between the president and his opponents is often termed a "war of words" and presidential statements are analysed, repeated and sometimes carved into stone. There is little doubt that speeches become a primary tool that citizens and scholar use to judge the historical legacy of a president. As Bradley Patterson (1988) put it, "Speeches and statements are the testament of each presidency."

A speech is most effective when the audience is challenged to engage with the message and the speaker's argument (Nguyen, 2017). Rottinghaus (2008:140) explains that the "implication for presidential leadership is that presidents should theoretically, be able to motivate public opinion in a way most favourable to their own policy preferences". Rottinghaus, in studying speeches by U.S. presidents in times of war, found that presidents use persuasive rhetoric with the intention to influence the public. Presidents used "crafted talk" to tailor their language on policy messages to fit public interest in order to have greater persuasive power (Grice, 2010:19).

For Atkinson (1984:1), "the technical skills necessary for composing and delivering a spellbinding speech" is a craft that only few politicians can master. Moreover, every good speech has methods that underlie its effective performance. Consequently, people can notice that some speakers inspire their audience while others do not. Thus, presidents must resort to substantive arguments to persuade public opinion rather than merely relying on rhetorical symbolism (Cohen, 1995). Generally, the public is disinterested in politics, therefore, to gain the public's attention a president may have to indicate that a policy problem is significant. The president may have to explain the reasons he/she took certain positions, thereby providing justification to the public and reinforcing the importance of that policy. Cohen (1995) suggests that taking positions on issues that raise ideological debate or adding explicit details about a policy is a form of substantiveness.

\section{Theoretical Foundations and Methodology}

The methodology for conducting this analysis draws upon Thoemmes and Conway's seminal work on Integrative complexity. It similarly advances rhetorical presidency as a theoretical instrument; focusing on a singular regime-presidency in Nigeria against the usual practice of comparative analysis. The aim of the study in relation to the three selected speeches (assuming that the aim of the President is to influence and motivate the Nigerian public or assert his course of action) is to interrogate whether the speeches were capable of persuading the citizenry or douse 
psychological and political tension (as the case may be) at the particular period when they were made.

The rhetorical presidency is both a structural theory and a theory of how presidents communicate in the media age. It draws from political science, history and communication studies (Medhurst, 1996). The study of the rhetorical presidency of a given leader is concerned with the way in which a president is driven by the rhetorical constructs found within the U.S. Constitution. In Speaking to the People: The Rhetorical Presidency in Historical Perspective Richard Ellis further considers the evolution of the role of the American President. Ellis (1998:1) stresses that prior to the late nineteenthcentury presidents "were to be seen and not heard". However, rather than Woodrow Wilson, President Roosevelt is credited by Ellis as being "the architect of the modern presidency" (1998:110). Franklin D. Roosevelt insisted on speaking directly to the convention that had nominated him, which was an unprecedented act.

After 1932 the presidential candidate's speech during the convention became a showcase event. Furthermore Roosevelt took advantage of the radio and the ability to speak directly to the people. Roosevelt governed to a new set of norms, and those norms, in turn, created a wholly new set of expectations within the mass public regarding presidential behaviour (Ellis, 1998:101). In comparison Martin Medhurst (2007) in "Rhetorical leadership and the presidency: A situational taxonomy" maintains that the American presidency has always been a position of rhetorical leadership. He stresses that rhetoric as the original form of leadership dates back to the first democracies in Ancient Greece, looking to Aristotle and Cicero he notes that rhetorical leadership is dependent on the character of the speaker and their ability to demonstrate their character to the public. In regard to the study rhetorical presidency, Medhurst (1996:xi) states:

...the primary focus and basic concern of those working within the construct of the rhetorical presidency is largely, if not entirely, institutional. They are most concerned with the nature, scope, and function of the presidency as a constitutional office.

The rhetorical presidency is both a structural theory and a theory of how presidents communicate in the media age. It draws from political science, history and communication studies (Gillespie, 2009:157). Since the term "rhetoric" is becoming more and more popular across the English-speaking mass media world, it should be specified that it is here taken in the classical sense of the word (Aristotle 1991: 22-24). The main function of rhetoric is to convince the hearer or audience about the necessity to address a specific topic. The speaker's moral character should surface in his speech and therefore help him gain the hearer/audience's confidence and trust. But rhetorical devices only work if the audience's passions are ignited by the speech itself (Bonnefille, 2011:147).

Rhetorical scholars have long been interested in studying the internal dynamics of political speech - not summarizing what is said, but rather describing how a speech works as a rhetorical appeal. In so doing, of course, one naturally examines the content of the discourse (its goals and strategies) in order to understand how the speaker seeks to influence an audience and to evaluate both the effectiveness 
of the speech as a rhetorical appeal and its ethical and political implications (Williams et al, 2012:1744). A significant change in modern presidential rhetoric is that it has, since the nineteenth century, become much more assertive: it has become activist, "realist," and confident (Lim, 2002:335).

The assessment of leaders in political science has traditionally relied upon several methods. Psychobiography (e.g., George and George, 1956) has tended to use archival documents, memoirs, and interviews in combination with concepts borrowed from psychoanalytic theory. Others, such as Woodward (2003 cited in Renshon, 2009:649), have relied primarily on interviewing the subject to gain insight into their beliefs, motives, and ultimately, their decisions. So-called "assessment at a distance" 1 has taken as its fundamental assumption the idea that useful (and revealing) information about political leaders can be gleaned from public speeches, if only one knows where, and how, to look. Within this epistemological umbrella is the analysis of leaders' conceptual and integrative complexity (e.g., Suedfeld \& Tetlock, 1977; Thoemmes and Conway, 2007 cited in Renshon, 2009:649).

Integrative complexity scholars define the term within the scope of two pairs of concepts: Differentiation/integration and simplicity/complexity. Differentiation refers to the articulation of a variety of message attributes within rhetorical material such as speeches, while integration refers to the consolidation and articulation of the interconnectedness of these attributes in a meaningful manner (Suedfeld and Tetlock, 1977). Integrative complexity, originally descending from Kelly's personal construct theory (1955), is a psychological construct that tries to describe the elaboration and complexity of any given information or thought. In order for them to be practically assessed, these thoughts can be expressed in a variety of ways, such as spoken language or written information in any format. The basic description of integrative complexity is defined "in terms of degrees of differentiation and integration" (BakerBrown, Ballard, de Vries, Suedfeld, and Tetlock, 1992:393). Differentiation refers to the ability to distinguish different view-points on an issue and to acknowledge them. A differentiated viewpoint consists of multiple alternatives and dimensions and shows an increased ambiguity tolerance that is not present in an undifferentiated viewpoint. Differentiation is the first step towards integration, which is defined as the "conceptual connection[s] among differentiated dimensions" (p. 393). A

This study extends previous research on the nature of presidential independence speeches to include the 2015 inaugural speech (the first of its kind by a victorious opposition candidate) and the 2017 post-medical vacation presidential speech (made to douse tension by the restless citizenry). Although political scientists who have been concerned with explicating the theory of the rhetorical presidency have been consciously more interested in the act of rhetoric - the quantity, timing, and location of speeches - rather than its substance (Lim, 2002:230), this essay shall deviate partly from this trend by beaming its searchlight on the psycho-political substance of the identified speeches of President Buhari with a view to establishing their persuasive potency in the short time and significant antecedent in the long term. 


\section{Background to President Buhari's Electoral Victory}

In high hopes that the Fourth Republic would usher in a liberal democratic era through the ballot box, rather than the bullet, Nigerians strived to confer legitimacy on elected public officials through re-election or by voting out those they viewed as having failed (Jega, 2016:13). The opening-up of the political space by the return to democracy has not only raised the hopes of hitherto marginalized or repressed groups; it has also raised the stakes in the competition for access to power and resources. Demands for inclusion have been strident, just as the politics of exclusion has been vicious (Egbefo, 2015:60). However, subsequent elections were still regarded as mere rituals whose outcome was predetermined, often with the highest bidder buying the elections. In some cases, it is widely believed that thugs and some members of the security agencies committed election fraud. It seemed that the citizens' genuine choices through voting did not count (Jega, 2016:14).

On a broader spectrum however, in spite of the relative political stability in almost two decades of democratic experiment, the challenges of service delivery, infrastructure deficits, economic hardship, and citizens' degraded quality of life, among others, have demonstrated that the polity is still bereft of the expected governance deliverables. It is against this backdrop, according to Aliu (2014), that the disenchantment and disappointment of many Nigerians with the impact of the current democratic experience on their socio-political and economic wellbeing can be appropriately understood and situated. Little wonder, there is massive decline in popular trust in democratic institutions, processes and political leadership.

The disenchantment of the citizens and their desire to have a clean break with this ugly past manifested on 28 March 2015 when the opposition won a multi-party election for the first time in Nigeria's history.

Former Head of State between 1983 and 1985, Buhari exited from partisan politics afterwards (Nwabughiogu, 2015). With the return to democracy in 1999, General Buhari contested presidential elections in 2003, 2007 and 2011, but lost to the People's Democratic Party (PDP) candidates. Buhari has been candidate of two different progressive political groups until the 2015 general elections: All Nigeria People's Party (2003 and 2007) and Congress for Progressive Change (2011) (Díez Alcalde, 2015). The retired army officer's journey to the presidency began in 2003 when he contested under the platform of the now defunct All Peoples Party, APP but lost to then incumbent President Olusegun Obasanjo of the PDP. In the 2007 presidential election, Buhari contested again on the ticket of the same party, but was beaten by PDP's Umaru Yar'Adua who scored 26,638,063 to his paltry 6,605,299. He contested as the CPC presidential candidate during the 2011 presidential poll, which he lost to President Goodluck Jonathan of the PDP. In that election, Buhari secured 12,214,853 votes against the President Jonathan's 22,495,187 (Onuoha et al, 2015:3).

On March 28, 2015, Nigerians went to the polls and voted decisively for change. Across the country, the conduct of the vote took place in a civil atmosphere, largely undisturbed by violence (Sweeney, 2015). The APC candidate got the highest number 
of votes in 21 states while the then incumbent President Jonathan prevailed in 15 states and Abuja. Mohammadu Buhari, who wields enormous support in Northern Nigeria, won in 21 states to emerge victorious (Ezeamalu and Adebayo, 2015). This election result challenged traditional notions suggesting that Nigeria's problems are based primarily on divisions between north and south, or Christian and Muslim populations. According to Carson (cited in Fornof and Ruder, 2015), while religious and ethnic identities remain political factors in the country's politics, the vote result suggests that, in this election, the key issues - security, corruption and the economyprevailed over identity politics to define a national aspiration for change. Buhari won also because many Nigerian voters wanted a change in leadership to halt deep and pervasive corruption, and to reduce poverty and unemployment.

Gen Buhari's victory is a hugely significant moment in Nigeria's turbulent history. Since independence from Britain in 1960, there have been numerous coups and most elections have been rigged. Of course in a close election, there will be many voters who are not pleased with this outcome but the whole process is a sign that democracy is deepening in Nigeria (BBC News, 2015). With this historic win, Buhari became the first opposition candidate in history of Nigeria to win a presidential election (GKToday, 2015). A day after winning Nigeria's presidency, Muhammadu Buhari told CNN's Christiane Amanpour (2015) that he plans to aggressively fight corruption that has long plagued Nigeria and go after the root of the nation's unrest. Buhari said he will "rapidly give attention" to curbing violence in the northeast part of Nigeria, where the terrorist group Boko Haram operates.

\section{Contextual Analysis of the Three Selected Speeches}

Content analysis has been widely used in studies examining various aspects of the presidency, such as verbal style, rhetoric, personality, images, etc. (See Toolin, 1983 and Kessel, 1974). The data for this paper were sourced from different newspapers in the country. As earlier indicated, presidents of nations deliver speeches as a response to particular national events, such as inauguration of a new administration, Independence Anniversary, Democracy Day, Workers' Day, among others, depending on the import of these special days to different countries. My aim here is to highlight an institutional basis for presidential power embedded in the executive particularly in a country like Nigeria through symbolic speech making.

\section{May 29, 2015 Inaugural Speech}

Presidential inaugural speeches have witnessed a rapid proliferation of research in the 21st century in the field of political discourse. Researchers harness presidential speeches as vital instrument for analysing social, economic and political issues in different parts of the world (Sani and Mode, 2015:30813). Presidential 
historians and most social scientists do not shy away from reading and analysing Presidential Inaugural Comments called speeches. Speech writers show that a president being sworn in will address the nation with how and what the nation is to be guided on for outcomes that will change lives and opportunities for growth by (Iroegbu, 2015). Thus, of all the contexts of presidential speeches, the context that is characterised most by public anticipation of a presidential speech is the presidential inauguration ceremony, which is designed to set the agenda for a new administration.

The inaugural speech of President Muhammadu Buhari was delivered at the Eagles Square, Abuja on 29th May, 2015 shortly after he was sworn in as the Executive President of the Federal Republic of Nigeria. The inaugural address was significant and attracted a lot of attention particularly because of the numerous negative realities in the Nigerian nation, most especially the precarious economic situation of the country, the high spate of insecurity and the political indecorum that marked the electioneering campaigns for the 2015 general elections (Ademilokun (2015:3) that seem unending and create a strong sense of despondency in the minds and souls of Nigerians (Sani and Mode, 2015:30815).

The speech was also remarkable for its candour (Campbell, 2015). On Nigeria's notorious poor governance: after paying tribute to the heroes of Nigeria's foundation, he said, "Some of their successors behaved like spoilt children breaking everything and bringing disorder to the house." Or, "The judicial system needs reform to cleanse itself from its immediate past. The country now expects the judiciary to act with dispatch on all cases especially on corruption, serious financial crimes, or abuse of office." After thanking Cameroon, Niger and Chad for committing their armed forces to the fight against Boko Haram inside Nigeria, Buhari said he wanted to "assure the wider international community of our willingness to cooperate" on a host of pressing issues, including cyber security and the fight against terrorism.

One central theme many people are talking about is the political nuance of which President Buhari laid bare, thus, "I belong to everybody and I belong to nobody". Some critics snub him for reducing those who invested their resources on him to bring him to power and for not being fair to appreciate them. Others praise him that he has shown what soldiers do with power and he will not be different to show courage when it matters. In other words, he is showing that by declaring that he belongs to nobody, political godfathers and godmothers around him should better watch him act for change (Iroegbu, 2015). Medubi and Amuda (2016) attempted a socio-pragmatic analysis of President Buhari's inaugural address with a view to elucidating 'the meanings encoded in the inaugural and the functions they perform in an actual context of use.' They concluded that the utterance 'I belong to everybody and I belong to nobody' was a true proposition of the speaker's intent, which was: to seek cooperation, team work, understanding and support from everyone in order to achieve true federalism, national development and unity.

It has often been observed by scholars that rhetoric is used to justify ideological values in argumentation. An inaugural speech therefore serves as a political philosophy and action through the voice of a president at the very important occasion 
of being sworn into office. Presidential inaugurals are crafted to spell out the vision and missions of a President. Such inaugurals are meant to win the people's support. Did President Buhari's speech achieve this? In his semantic approach, Ademilekun (2015) examined aspects of attitudinal meaning in President Buhari's inauguration speech, using Appraisal theory of Martin and White (2005). His conclusion was that the president had deployed effectual meanings, judgments, and appreciations in order to achieve his aim of connecting effectively with his audience.

An effective speech is constructed on the foundation of a big idea, the purpose of the speech that is strengthened throughout the speech with simple repetition. For a presidential inauguration, the big idea, or purpose, is the incoming president's vision for the next four years and the principles on which this vision is based (Nguyen, 2017). For President Buhari, the inaugural speech captures the essence of the major ills confronting the country, such as the insecurity, pervasiveness of corruption, parlous state of the economy, lack of power and unemployment and how the government under his watch would tackle these challenges. The president also went down memory lane and spoke about the nation's founding fathers, their vision, contributions and aspirations for the country, while relating it to the failure of successive leaders to build on the legacy bequeathed by the heroes of our independence.

Although, he promised true federalism, with a revamping of the relationships between the executive, legislative, and judicial functions at the federal level, and between the federal, state, and local governments, "it is intriguing why PMB chose to make a distinction between those who voted for him and those who did not. It was distractive and greatly detracted from the profundity of the speech" (Mimiko, 2015).

\section{October 1, 2016 Independence Speech}

In his second independence day speech, President Muhammadu Buhari spoke on issues of interest ranging from calls for restructuring, the federal government's diversification policy for the economy, institutional reforms in the nation's political landscape and efforts aimed at restoring peace and security to the country. However, keen observers of President Buhari's speeches would have been taken aback by his constant recourse to apportioning blames for the current economic straits into which the nation is seemingly irretrievably entangled. At some point, it was convenient to blame the immediate past regime of Jonathan for squandering the nation's resources due to its inability to save for the proverbial rainy day. At another, he collectively held accountable the PDP governments spanning through the regimes of Obasanjo, Yar' Adua and Jonathan for this pass.

At a period when lives and property are insecure as sundry crimes are perpetrated across the land; when social services and public infrastructure are of the poorest quality imaginable and there is a huge and ever increasing gulf of inequality between the rich and the poor, the national mood is further depressed by revelations of the looting of the national treasury on a horrendous and industrial scale in the last 
dispensation. Thus, the president's second independence speech was expected to shift the narrative to how the administration intended to salvage the precarious and anomalous situation with a view to assuaging the citizens' predicament and disillusionment. Although, the president glaringly showed empathy to Nigerians and efforts of the Federal Ministry of Agriculture and the Central Bank to encourage local production of rice, maize, sorghum, millet and soya beans, a seemingly sceptical citizenry wanted assurance of proper implementation. On economic recession, the President said:

I know that uppermost in your minds today is the economic crisis. The recession for many individuals and families is real. For some, it means not being able to pay school fees, for others it's not being able to afford the high cost of food (rice and millet) or the high cost of local or international travel, and for many of our young people the recession means joblessness, sometimes after graduating from university or polytechnic.

While the President showed concern on the lingering plights of his fellow citizens, Nigerians were also justified to be angry and confused because for a whole year before the Independence Speech, the challenges for them were overwhelming. Widespread insecurity threatened national cohesion and promoted mistrust; the absence of sound economic policies and projections also put the nation in dire financial straits; nearly all states of the federation were unable to pay salaries.

Thus, at a time the parlous state of the economy was stimulating a debate about the quality of the president's team, Nigerians, would like to be comforted by inspirational words and actions that would engender a glimmer of hope, that all will be well, after all. At that time, more than mere seeming sympathy, Nigeria needed a president who would tell the people how he intended to remove all obstacles to industrialization in Nigeria. Nigeria needed a leader who would tell the people how he intended to deal with the issues of "ease of doing business".

While admitting that terrorism is an ongoing battle the government is deeply involved in, Buhari maintained that the armed forces had made remarkable strides in scaling down the security threats by Boko Haram and other insurgents. He noted that: 'Nigerians should thank our gallant men of the Armed Forces and Police for rescuing large areas of the country captured by insurgents. Now, residents in Borno, Yobe and Adamawa States, as well as several neighbouring states go about their daily business in relative safety.' It was good the President reeled out the score cards on the security front with appreciation to the gallantry of the Army and the police. The President rightly acknowledged the resurgence of new criminalities namely kidnappings, armed robberies and Niger Delta militancy which serially blew up gas and oil pipelines undermining Crude oil production. However the president sounded more academic with warnings than being presidential on the new insecurity (Aremu, 2016). 


\section{August 20, 2017 Post-Medical Vacation Speech}

In 2017, President Buhari spent more than four months in London, receiving medical treatment for an undisclosed illness (Akinnaso, 2017). The President of Africa's most populous nation on assumption of office in May 2015 had earlier embarked on a six-day vacation in the United Kingdom between February 5 and 10, 2016. On June 6, 2016, he embarked on another 10-day vacation to attend to what the Presidency described as "persistent ear infection" (See Uwugiaren and Soniyi, 2016). The 74-year-old Nigerian leader again left the country on January 19, 2017, which he prolonged due to doctors' advice. He set out for another vacation on May 7 before returning on August 19. He spent a total of 104 days abroad, making him the first President in Nigeria's history to be away for such a long time. Certainly, the rumour surrounding the true nature of the illness grew from anxiety to fear in the country. And the dark clouds over the exact nature of what was wrong with Nigeria's president led to another past time: trips by the Acting President, the President's wife, political party chieftains and some governors to the UK, all in a bid to manage the huge public relations crisis that has dogged the absence of the president.

He returned to a country that is riven by mutual suspicion along ethnic and sectarian lines, deepening insecurity and an economy in recession, and with neither a firm direction nor a steady hand on the wheel (The Punch, 2017). Like almost all events in Nigeria in recent times, his illness and absence from duty have reopened the deepening fissures in the polity, provoking protests and support in equal measure (The Punch, 2017).

President Muhammadu Buhari delivered a public speech for the first time since returning from three months of medical treatment. The presidential address was principally designed for gratitude to the people over prayers, inspirations and love extended to him while out of the country (Umegboro, 2017). The Nigerian public looked forward to a robust speech that would boost the confidence of the people in the capacity of the government to continue to take on the huge challenges of governance (Nnorom, 2017) even though he left no vacuum as he legally transmitted power to hid deputy. Did he address the right issues and speak to the nation's distress? The brevity of his speech appears deliberate. It was simply designed to read the riot act to a few promoters of discord, particularly those campaigning for separatism (Akinlotan, 2017). The President rightly noted in his broadcast that the social media platforms have become battle grounds for wars of words and evil rhetoric of groups against one another, and the unfortunate aspect is that the youths that will cohabit and lead this country in the near future are the most enthusiastic combatants. This is, no doubt, a dangerous trend to be tamed. The president called for unity and pledged to tackle terrorism and security threats:

I am pleased to be back on home soil among my brothers and sisters. But I was distressed to notice that some of the comments, especially in the social media have crossed our national red lines by daring to question our collective existence as a nation. Nigeria's 
unity is settled and not negotiable. We shall not allow irresponsible elements to start trouble.

The comments were widely interpreted as a rebuke to separatists calling for an independent state of Biafra in the South of Nigeria. The President went on to list a series of security threats including Boko Haram, clashes between herdsmen and farmers, and sectarian violence "fueled by political mischief makers." Ethnic tensions - with some calling for a separate state in the south-east known as Biafra - surfaced during his leave, while the war against the Islamist militant group Boko Haram continued in parts of the north. Indeed, divisions within the Nigerian polity have seen a spike in the clamour for a fundamental restructuring of the country to make it a true federation and end institutionalised injustice: some fringe groups insist on outright secession, while the truce brokered with armed groups in the Niger Delta region, shaky at best, has virtually broken down. While he agreed that there are indeed "legitimate concerns" and that "every group has a grievance", the president said "the beauty and attraction of a federation is that it allows different groups to air their grievances and work out a mode of co-existence."

Thus, much of President Buhari's short speech seemed directed at those rivals, some of whom engaged in a bloody civil war decades ago to create an independent republic of Biafra in the southeast (Searcey and Iyare, 2017). The president singled out foes who "have crossed our national red lines by daring to question our collective existence as a nation. This is a step too far. Nigeria's unity is settled and not negotiable. We shall not allow irresponsible elements to start trouble, and when things get bad they run away and saddle others with the responsibility of bringing back order, if necessary with their blood"(Searcey and Iyare, 2017). Buhari's long absences for an illness that officials refused to identify, created tensions in Nigeria, setting off protests not only from separatists in the south but also from poor residents of oil communities who want a better life and from ordinary citizens who wanted the president to either come home or resign.

In an obvious response to calls by the Arewa Youth group asking Igbos to leave the North by October 1st and counter call by groups in the South East, Buhari clearly stated that every Nigerian has the right to live and pursue his business anywhere in Nigeria without any hindrance (Archibong, 2017). The President affirmed that "grievances" by groups could only be handled the National Assembly and the Council of State, which he noted are the "appropriate and legitimate bodies for national discourse." He urged Nigerians to eschew petty differences and come together to face common challenges of; economic security, political evolution, and integration as well as lasting peace among all Nigerians" (Archibong, 2017). But directing agitators of the nation's restructuring to the council of state or the National Assembly where the issue was aborted during the constitutional review exercise amounts to not appreciating the enormity of neglecting the loud cry of the victims of the status quo. 
In terms of content analysis, the speech was rather too fleeting to speak to the nuances of burning national issues the president obviously wanted to address. It is argued that the broadcast did not encompass the "holistic situation of our present situation and with due considerations for the divergence of opinions as far as moving the entity called Nigeria forward positively" (See Opejobi, 2017). Perhaps, sensitive as it is important and critically contributing to the increasing distrust and disunity in the nation, is the issue of restructuring as canvassed by major regions across the country. For decades, sections of the country have decried the level of development in the regions, attributing it to what they say is a sloppy design that left those everyone at the mercy of whoever controls the central government (Oba, 2017). But by illustrating his speech with a discussion he said he had with the late Emeka Ojukwu, leader of the 1967-1970 Biafra rebellion in the Eastern Region, the president all but indicated that his chief animus was targeted at Nnamdi Kanu and his Indigenous People of Biafra (IPOB) self-determination group (Akinlotan, 2017). Clearly, Buhari, being a war-tested General, seems obsessed with only the security dimension of the national question. By recalling his extensive conversation in 2003 with Emeka Ojukwu, Buhari appears too eager to demonstrate to neo-Biafrans the futility of seeking to disinter the old sepulchre (Odion, 2017).

Generally, the speech exposes two terrifying details. The first is that, irrespective of the president's vaunted conversion to democratic ideals, he is at bottom averse to the liberal principles that undergird democracy. Reflecting his sour mood and impatience, the president suggests in the very first paragraph of his speech that questioning the collective existence of the nation amounted to crossing 'national red lines' (Akinlotan, 2017). Far worse is the fact that the speech clearly and unequivocally indicated the president's sole preference for law enforcement as a tool for securing national peace, unity and understanding. He shows no inclination to scientifically analyse the factors that engender the separatist campaigns that infuriate him, let alone decide and design options that would intelligently tackle and exterminate the malaise.

Overall, it is reassuring to hear Buhari speaking firmly, restating his promise to tackle decisively merchants of hate, kidnappers and "farmers versus herdsmen clashes" (sic). But the president needs to understand that these are only symptoms of deep structural defects long detected in the federal union. What remains is to summon the political courage to fix things and guarantee the union's sustainability. Issuing threats or deploying maximum force will, at best, only secure temporary relief. Without rooting out the cancerous growth, administering tranquilizers today is tantamount to the laughable futility of thinking that merely changing the sitting order in a Titanic in the face of an approaching iceberg will eviscerate the looming existential threat (Odion, 2017).

Buhari did not address the question of his health, which has been the subject of rampant speculation. Online activists have circulated the hashtag \#ResumeOrResign in a bid to end what they see as damaging uncertainty (Monks, 2017). As far as transparency goes and given Nigerians' love for and patience with their leader, the people cannot accept the rationalisation by the president's spokespersons that the 
President's wellbeing is his private matter (The Guardian, 2017). By openly declaring himself fit but waiting for the doctor's formal discharge, president Buhari had inadvertently made himself vulnerable to accusations of "moonlighting" away in London while the situation at home was growing precarious (Odion, 2017).

Lastly, at the time of his return, expectations were that the president would reshuffle his cabinet to inject new blood, as not much other than politics, had changed in most ministries in the first two years of the administration and reason for which hunger, poverty and unemployment have had negative effects on the nation as against campaign promises to address them head-on. This would have been a soothing balm to many Nigerians who had rated the ministers low in performance.

\section{Conclusion}

This paper has added to the exiting body of knowledge on rhetoric. It affirms that presidential speeches reflect the inner workings of a president's mind, bringing out the real man, much the same way impromptu interviews do (Akinlotan, 2017). The tone of a speech is reflected in careful word choice, sentence structure, and organization of information. If the tone, or style, of the information contradicts the intended purpose of the speech, the audience will misunderstand the message (Nguyen, 2017). Also, body language tells another story because stage presence is just as important as the words in the speech (Nguyen, 2017).

Peil (1991) observes that the popular image of the Nigerian politician reflects a singular dearth of moral guidance, especially in his public announcements. The Nigerian political atmosphere, for decades, has been characterised with insincerity, lies and greed. In all of this, the prevalent public disillusionment occasioned by severe economic hardship is being capped by a thorough sense of betrayal of election promises which the highlighted speech ought to address with a view to assuaging the tension in the polity and bringing succour to the troubled citizenry. Therefore, the responsibility is now on President Buhari to move quickly to retrieve his administration from "the vice-grip of embarrassing incompetence, worrisome clannishness and shrinking nationalism" (This Day, 2017) as he concludes his first term in office. During those national critical moments, the president can assume immense public support for his course of action in such situations because the public sees the president as the "personification of the country". 


\section{References}

Ademilokun, Mohammed (2015) Aspects of Attitudinal Meaning in Nigerian President Muhammadu Buhari's Inauguration Speech: An Appraisal Analysis, The African Symposium, Volume 15, No. 2, December 2015 Akinlotan, Idowu (2017) Buhari's controversial speech, The Nation, August 27 Aliu, M. (2014) The State, Development and Governance in Africa: The Nigerian Experience, IOSR Journal of Humanities and Social Sciences (IOSRJHSS) 19(4) Ver. I (Apr. 2014): 21-32

Archibong, Elizabeth (2017) Buhari reads riot act, insists nation's unity not negotiable, Business Day, August 21

Aremu, Issa (2016) Nigeria: Buhari's Independence Day Speech - a Content Analysis, Daily Trust, October 3

Atkinson, M. (1984) Our masters' voices: the language and body language of politics, London: Routledge

Baker-Brown, G., Ballard, E. J., Bluck, S., de Vries, B., Suedfeld, P., \& Tetlock, P. (1992) The conceptual/integrative complexity scoring manual. In C. P. Smith (Ed.), Motivation and person ality: Handbook of thematic content analysis (pp. 400-418). Cambridge: Cambridge University Press

BBC News (2015) Nigeria election: Muhammadu Buhari wins presidency, April 1 Bonnefille, Stéphanie (2011) A cognitive rhetoric approach to two political speeches Obama and Sarkozy's remarks at the U.N.'s Climate Change summit (2009) Anglophonia/Sigma, 15 (30) | 2011, 145-162

Campbell, John (2015) Nigeria President Muhammadu Buhari's Inauguration Address, Available at: https:/ / www.cfr.org/blog/nigeria-presidentmuhammadu-buharis-inauguration-address

Chilton, P. A. (2004). Analyzing Political Discourse: Theory and Practice, London: Routledge

CNN (2015) Nigeria's president-elect, Muhammadu Buhari says he will fight corruption, April 1

Cohen, J. E. (1995). Presidential rhetoric and the public agenda, American Journal of Political Science, 39(1), 87-107

De Wet, J.C. (2010) The Art of Persuasive Communication- A Process, Claremont: Juta \& Company Ltd.

Denton, R. and Hahn, D. (1986) Presidential Communication, New York: Praeger

Edwards, G. C. and Wood, B. D. (1999) Who influences whom? The president, congress, and the media, The American Political Science Review, 93(2), 327-344

Egbefo, Omolumen Dawood (2015) Fifteen Years of Democracy, 1999-2014: Reflections on Nigeria's Quest for National Integration, AFRREV, VOL. 9(2), S/NO 37 
Elections in Nigeria: Buhari's Victory and its Challenges for the Future, Available at: http://www.ieee.es/en/Galerias/fichero/docs_analisis/2015/DIE EEA20-2015_Nigeria_Elecciones_JDA_ENGLISH.pdf

Ellis, R. J. (1998) Speaking to the people: the rhetorical presidency in historical perspective, Amherst: University of Massachusetts Press.

Eshbaugh-Soha, Matthew (2010) The Politics Of Presidential Speeches, Congress \& the Presidency, 37:1-21

Ezeamalu, Ben and Adebayo, Hassan (2015) Buhari in historic election win, emerges Nigeria's President-elect, Premium Times, March 31

Fornof, Emily and Ruder, Steven (2015) Democratic Vote Offers Nigeria a Chance to Rebuild, and to Lead Africa, U.S. Institute of Peace, April 10

George, A. L., \& George, J. (1956) Woodrow Wilson and Colonel House: A personality study, New York: Dover Publications.

Gillespie, Andra (2009). Whose Black Politics? Cases in Post-Racial Black Leadership. Routledge

GKToday (2015) Muhammadu Buhari elected as President of Nigeria, April 1

Grice, Patricia Joyce (2010) Presidential Communication to Children: An Analysis of Persuasive Strategies in Presidential Speeches, A Thesis Presented to The Faculty of the Department of Communication Western Kentucky University Bowling Green, Kentucky In Partial Fulfillment Of the Requirements for the Degree Master of Arts

Hughes, Jessica Lynne (2009) Analysing Policy Issues in Presidential Speeches And The Media: An Agenda-Setting Study, A thesis submitted in partial fulfilment of the requirements for the Master of Arts Degree in Journalism and Media Studies Hank Greenspun School of Journalism and Media Studies, Greenspun College of Urban Affairs Graduate College, University of Nevada, Las Vegas

Irimiea, S. A. (2010) Rhetorical and Comparative Study of the Victory Speeches of Barack Obama and Mircea Geoana, Journal of Linguistic Intercultural Education, Vol. 3, p41-53

Iroegbu, Patrick (2015) On the Inaugural Speech of President Buhari, Available at: http://chatafrik.com/articles/politics/on-the-inaugural-speech-ofpresident-buhari\#.Wb-1lciGPIU

Jega, Attahiru M (2016) Towards Effective Elections in Nigeria, The International Elections Advisory Council, Available at: http://www.thefutureofelections.com/download/the-future-ofelections-report.pdf

Kamalu I. and Agangan R. (2011) A critical discourse analysis of Goodluck Jonathan's declaration of interest in the PDP presidential primaries‘ Language Discourse \& Society, 1(1), 32-53.

Kelly, G. A. (1955) The psychology of personal constructs. New York: Norton Kessel, J (1974) The Parameters of Presidential Politics, Social Science Quarterly, 55:8- 
Lim, Elvin T. (2002) Five Trends in Presidential Rhetoric: An Analysis of Rhetoric from George Washington to Bill Clinton, Presidential Studies Quarterly 32 , no. 2 ( June)

Medhurst, M. J. (2007) Rhetorical leadership and the presidency: A situational taxonomy. In T. L. Price and J. T. Wren (Eds.), The values of presidential leadership (pp. 59-84). New York: Palgrave Macmillan.

Medhurst, Martin J (1996) "Introduction" in Beyond the Rhetorical Presidency, Martin J. Medhurst (ed.), College Station: Texas A\&M UP, XI-XXV. Print.

Medhurst, Martin J. (1996) Beyond the Rhetorical Presidency, Texas A \& M University Press. p. XI=XXV. ISBN 978-0-89096-710-2

Medubi, O. and Amuda, F. (2016). 'I belong to everybody and I belong to nobody': A socio-pragmatic analysis of president Buhari's inaugural address. IJRDO-Journal of Social Science and Humanities Research 1 (8): 1-31.

Mimiko, Femi (2015) Of Inauguration Speech and Ominous Signs, Available at: https://www.pressreader.com/nigeria/thisday/20150607/282230 894307191

Monks, Kieron (2017) Nigerian President delivers first speech after mystery illness, CNN, Updated 2026 GMT (0426 HKT) August 21, 2017

Nguyen, Kenny (2017) 5 Presentation Techniques Presidents Use To Impact an Audience [Featuring Inauguration Speeches], Available at: http://bigfishpresentations.com/2017/01/20/5-presentationtechniques-presidents-use-to-impact-an-audience-featuringinauguration-speeches/

Nwabughiogu, Levinus (2015) “My tortuous election journeys - Buhari”, Vanguard, May 10

Oba, Abdulwahaab (2017) Buhari's return and expectations, The Nation, August 30 Onuoha, Freedom et al (2015) Political, Economic and Security Challenges Facing President Buhari, Al Jazeera Centre for Studies, September 21

Opejobi, Seun (2017) Buhari: Group 'attacks' President over silence on salient issues, Daily Post, August 21

Patterson Bradley H. (1988) The Ring of Power: The White House Staff and its Expanding Role in Government, New York, Basic Books Inc.,Publishers

Peil, M. (1991). Lagos: The City is the People. London: Belharen Press

Renshon, Jonathan (2009) When Public Statements Reveal Private Beliefs: Assessing Operational Codes at a Distance, Political Psychology, Vol. 30, No. 4 Sani, Ibrahim and Mode Muhammad (2015) Presidential Inaugural Speeches as Vital Instrument for Setting Agenda in Nigeria: An Appraisal of President Muhammad Buhari's Inaugural Speech, International Journal of Current Research Vol. 8, Issue, 05, pp.30813-30817

Searcey, Dionne and Iyare, Tony (2017) President Buhari Returns to Nigeria, Facing Serious Challenges, The New York Times, August 21 
Suedfeld, P., and Tetlock, P. (1977) Integrative complexity of communications in international crises. The Journal of Conflict Resolution, 21(1), 169184

Sweeney, William (2015) Nigeria's 2015 Elections: A Critical Vote for Democracy in Africa, IFES, March 31

Teittinen, M. (2000) "Power and Persuasion in the Finnish Presidential Rhetoric in the early 1990's" (Retrieved from the Internet, 14 September, 2017) http://www/natcom.org/conferences/finland/mariteittinen

The Guardian (2017) Buhari's illness: The need to know, August 14

The Punch (2017) Buhari's speech, a missed opportunity - PDP, August 22

The Punch Editorial (2017) Now that Buhari is back, August 22

This Day (2017) Buhari's Troubled Presidency, October 8

Toolin, C (1983) American Civil Religion from 1789 to 1981: A Content Analysis of Presidential Inaugural Addresses, Review of Religious Research, 25:39-48

Umegboro, Carl (2017) Much Ado about Buhari's speech and the Rodents' invasion, Daily Trust, August 26

Uwugiaren, Iyobosa and Soniyi, Tobi (2016) Finally, Presidency Admits Buhari Has Ear Infection, ThisDay, June 6

Williams, David C.; Young, Marilyn J. and Launer, Michael K (2012) A Methodology for Analysing Political Speech: Western Approaches to Rhetorical Theory, Journal of Siberian Federal University. Humanities \& Social Sciences 12 (2012 5) 1744-1752

Windt, T. (1986) Presidential rhetoric: Definition of a field of study, Presidential Studies Quarterly, 16(1), 102.

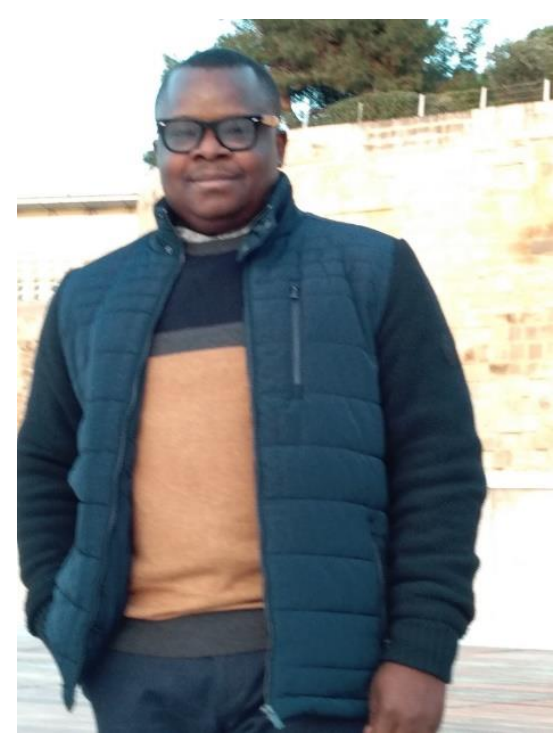

Mike Omilusi studied at Ekiti State University, Nigeria and obtained a PhD in Political Science in 2014. He has, for over a decade, been teaching and researching issues related to political sociology, democratisation, gender and conflict studies in Sub-Saharan Africa. Before 2009 when he joined the University's academic staff, he had worked with civil society organisations in Nigeria for seven years and awarded the Best Democracy Monitor in Nigeria by the Justice, Development and Peace Commission. He has wider exposure as a researcher, humanitarian volunteer, essayist and consultant with government, civil society groups and international organisations. He is an active player in the current democratization process in Nigeria with particular reference to civic education and election monitoring. 